\title{
Eukasz Borowiecki
}

\section{Ph.D. Student, Warsaw School of Economics \\ Historical Roots of Generalized Trust in Polish Society}

\begin{abstract}
The article analyses how historical events shape generalized trust in contemporary Polish society. The analysis consists of a set of logistic regression models. The impact of historical variables is controlled for age, sex, education and the size of the municipality. This is the first quantitative study on Poland that links historical events with the current levels of trust among Polish citizens. The common knowledge is that the Partitions of Poland had negative impact on trust. Literature on the topic hints that historical demographics should play a role too. The findings suggest that Partitions had little impact with only Greater Poland and Pomerania having lower levels of generalized trust. Historical literacy rate and the presence of Ukrainian or Belarusian population are negatively associated with generalized trust while the abrupt migrations after the World War I are positively associated. The rapid character of migration is supposed to positively impact generalized trust by forcing individuals to cooperate and rely on people with whom they have no personal ties.
\end{abstract}

Keywords: Social capital, trust, Poland, economic history JEL: J11, N34, N44, O17, Z13

\section{Introduction}

The aim of this paper is to look for historical roots of low trust in modern Polish society. When thinking about which factors are responsible for the current state of affairs, usually Polish scholars will point at the history of the country. The list of culprits is usually the same and these are the history of partitions, two World Wars, uprisings, communism, legacy of serfdom (abolished only in XIX century) or the tradition of political anarchy in 
pre-partition Poland. To pick two examples, Jerzy Regulski, who was responsible for the Polish 1999 municipal reform, points specifically at Partitions of Poland and communism as responsible for distrust towards the state and deficits in civic culture [Regulski, 2013]. Aleksander Smolar, President of the Board of Stefan Batory Foundation, argues in a very similar fashion. Namely, Partitions of Poland along with the experience of communism and military occupation are all responsible for the distrust among Poles [Smolar, 2014]. Such views are held as well among non-academics. Still, this common knowledge has not been, up to now, a sufficiently researched topic. More importantly, there are no quantitative studies which would link generalized trust or, more broadly, social capital in contemporary Polish society with the history of the country. The goal of this paper is to add to our understanding of how history shaped the current culture of low trust in Poland. The paper focuses solely on the interwar period and makes use of the data from the 1921 and 1931 Polish censuses.

Since the fall of communism Poland has experienced a considerable economic success. It was able to revamp its economy fast and push it from centrally-planned model to a market economy. Since then, it grew on average at around 4 percent, becoming one of leaders of growth in Europe. It was able to fix many of its domestic problems. In the last decade it was able to raise the quality of primary and secondary education to a level that is well above the OECD average [OECD, 2013]. Furthermore, it extended university education to many young Poles achieving a sharp rise in the number of tertiary education graduates [EACEA/Eurydice, 2012, p. 104]. Both are proofs of a large investment in human capital. In recent years, it managed to reduce economic disparities too. This can be easily highlighted by a reduction in Gini coefficient from 35.6 to 31.1 between 2005 and 2011, as reported by the Polish Central Statistical Office [GUS, 2012, p. 158]. In many ways, Poland in the last 25 years can be described as a success story.

Despite these achievements one cannot be fully optimistic about the prospects of the country as problems loom on the horizon. Similarly to other post-communist societies, Poland suffers from a low level of trust [Delhey, Newton, 2005]. People do not trust each other and are unwilling to cooperate. This goes hand in hand with a low appreciation of common good, acceptance for avoiding the law or even ordinary corruption [a good description of these negative phenomena is available in Diagnoza Społeczna, 2013]. This inability of solving collective action problems has both economic and social effects. Economy pays a hefty price of high transaction costs due to the culture of low trust. Once the perspective is shifted to the years to come, low trust may be a major hindrance in the development of a modern knowledge-based economy. Distrust generally does not go in line with innovativeness and risk-taking. On the other hand, societies where trust is abundant are among the most technologically advanced and they are home to many multinational companies as well as various start-ups (e.g. USA or Scandinavian countries).

In social terms, a society of low trust is less likely to be hospitable. Distrust will close an individual in a small group consisting primarily of relatives and close friends. 
Citizens who do not trust one another show less propensity to cooperate and, if they do, such cooperation will more likely create conflict and frustration. Rent seeking appears to be an attractive choice under such circumstances. Trust is simply very important for the general well-being of the population. All in all, the importance of social capital and trust cannot be overstated. It is a major issue for both Polish society and the economy of the country.

The primary contribution of this paper is to test the hypothesis that Polish partitions in years 1795-1918 had a detrimental effect on the level of trust. This hypothesis cannot be tested directly as obviously no counterfactual is available. Still, the fact that current Poland consists of three ex-partition lands (historically controlled by Germany, Austria-Hungary and Russia) and ex-German lands joined into Poland in 1945 gives a possibility of shedding some light on the issue. The scale of differences between outcomes for each region should at least point at the scale of the impact that the partitions could potentially have.

The second contribution is the verification of hypotheses that migration, literacy rate, urbanization and ethnic composition of pre-war Poland had impact on the level of trust in contemporary Polish society. Especially, migration, literacy rate and ethnic composition are known to have impact on trust and social capital. For example immigration is known to have an "ancestor" footprint - immigrants take with them the culture of trust characteristics of their home country [Rice, Feldman, 1997; Soroka, Helliwell, 2006]. Historical literacy, are supposed to have positive effect on trust [Tabellini, 2005; Guiso, Sapienza, Zingales, 2010].

The analysis presented in this paper focuses solely on generalized trust which is a subcomponent of social capital. It is measured by the standard Rosenberg question ("most people can be trusted" vs. "you can't be too careful in dealing with people"). Other, more elaborate measures of social capital are not used in the analysis. This approach is both theory and data-driven. The Social Diagnosis [Diagnoza Społeczna] dataset used in the analysis does not offer a sufficient set of variables that allow constructing an indicator which would fit with those used in the literature. The 2013 wave of the panel has an updated set of variables which enables the construction of a more proper indicator. However, this would mean restricting the analysis only to 2013 subsample. In addition, the outcomes from the Social Diagnosis dataset show that generalized trust is only weakly correlated with other measures of social capital such as associational life, acceptance of bribery, number of acquaintances. Generalized trust is often used as a proxy for social capital because it has the most predictive power. For example, in one of his research Putnam uses a complex index of social capital based on several sources of measures. However, it is generalized trust that turns out to be most correlated with the overall index [Putnam, 2000]. For these reasons, in the paper, generalized trust is used as the proxy variable indicating of social capital. 


\section{Literature Review}

The research on social capital and trust took off in the 1990s. Nonetheless, it has its root in the works of social scientists in previous decades. Already in the 1960s, Almond and Verba [1965] suggested to place more emphasis in political sciences on softer variables such as values and attitudes. They suggested that civic culture of citizens does play a major in tailoring the political life and a researcher should not focus narrowly on formal institutions. Pierre Bourdieu [1986] introduced the term social capital, however, he used it in a different fashion than it is done contemporarily. In essence, for Bourdieu social capital has a negative flavor. It is the cumulative sum of social networks that enables those, who are socially privileged, to preserve the preferable social structure. The notion of social capital was as well put forward by James Coleman. His influential 1988 paper shows how low social capital among parents results in increased drop-out rate among their children [Coleman, 1988].

In the last decade of XX century, social capital as a research program finally entered mainstream science. First came the study by Putnam on social capital in Italy [Putnam, 1993]. Putnam showed how differences in associational life and trust towards others can explain the rift in economic outcome and social life between Northern and Southern Italy. The regions that had less effective governments, mostly southern, could be characterized by a culture of distrust towards others and a focus on family. Putnam's argument is that these contemporary differences were shaped by centuries of different socio-economic institutions. Such view rests on an assumption that the culture of trust (or distrust) is passed from generation to generation. Research by other scholars proved that this is the case [Bjørnskov, 2007; Uslaner, 2002]. Trust is remarkably stable over time. This offers an attractive framework for research. If the current shape of civic life and trust among citizens is shaped by history then analyzing the historical roots of contemporary civic culture appears to be an attractive path for research. Another early proponent of research on trust was Francis Fukuyama [1995] who argued that the role of trust has been downplayed by economists. In his view, Japan and USA are both high-trust countries and it is trust that lies at the root of their economic success. Conversely, the underperformance of Russia or African countries stems from the low trust among their populations.

The rising wave of interest in social capital soon attracted critical views. In 1995, Robert Solow, in his comment to Fukuyama's 1995 book, criticized the over-optimism of proponents of social capital [Solow, 1995]. His argument was simple - if it is indeed a form of capital then it has to be measurable, offer non-negative economic payoff and be clearly different from human capital. It should as well be subject to investment and depreciation. In many ways, this critique is still relevant today.

In 2000, Putnam published his widely cited book Bowling Alone which tells the story of falling social capital in USA [Putnam, 2000]. Putnam argues that the story of American 
associations, pinpointed by de Tocqueville in early XIX century, becomes increasingly obscure. Americans become less trusting towards their government and other citizens. Their participation in voluntary organizations is dropping as does the voter turnout. Putnam points at a few factors that are potentially responsible for this phenomenon. These are rise in TV consumption, increase in the female labor participation, rise of urban sprawl and generational change. This thesis was often disputed. Critics argued that the effect of television is overstated because the rise of TV consumption among children is a direct outcome of increased female labor participation [Bianchi, Robinson, 1997]. Others make a case that rise in women participation in the labor force and higher neighborhood heterogeneity are both responsible for the weakening of associational life [Costa, Kahn, 2003]. In a way, reduction in social capital is a by-product of removing discriminatory barriers for women and minorities. Regardless of the cause, it is true that nowadays Americans trust each other less and are less likely to participate in associations than they were half a century ago. The same pattern can be observed not only in USA but as well in many developed countries with the exception of Scandinavia [Halpern, 2005].

There is a clear link between social capital and economic growth. Countries with a higher generalized trust are more affluent. They do as well grow faster and this effect is statistically significant even when controlled for other variables [Hall, Jones, 1999; Zak, Knack, 2001]. The usual explanation is that trust increases the efficiency of social exchange. As Durlauf and Fafchamps [2005] argue, social capital can be compensation in a state where Pareto-efficient solution cannot be achieved. Social capital may reduce problems regarding imperfect information, free-riding, enforcement, negative externalities and others. An influential work by Granovetter [1975] shows how social networks are used to spread information on the job market. Barr [2000] argues that social capital is used to pass information on new technologies among entrepreneurs in Ghana. Johnson, McMillan and Woodruff [2000] show how social networks among entrepreneurs in CEE countries allow for punishing those who break contracts.

There are many proofs that social capital and trust are passed from generation to generation. Uslaner [2002] and Delhey and Newton [2005] show that country scores on generalized trust are very stable over time. Furthermore, trust is positively correlated with historical levels of education and a history of political participation [Guiso, Sapienza, Zingales, 2010]. On the other hand, factors that are negatively correlated are community heterogeneity and immigration [Alesina, La Ferrara, 1999, 2002]. Major historical events have impact too. Nunn and Wantchekon [2009] show how history of slave trade in Africa had negative effects on generalized trust.

One of the important findings is that family values are negatively correlated with generalized trust, civic and political engagement [Alesina, Giuliano, 2009]. Ermisch and Gambetta [2010] use the idea of "outward exposure" as an umbrella term for all the factors that force an individual to cooperate with people outside their family. They argue that even negative experiences, such as divorce, that loosen family ties will lead to increased 
generalized trust. Two reasons are responsible for such mechanism. Firstly, an individual cooperating with people who are not members of the family is able to learn how to distinguish the trustworthy from those who can potentially cheat. Secondly, once the family ties become weak, one has no other choice but to rely on others. An interesting finding that supports this concept is presented by Durante [2009]. He shows that historical rainfall and temperature variability for years $1500-1750$ is positively associated with generalized trust in contemporary European societies. If the weather is unpredictable then it makes little sense to rely solely on your close family for support. After all, if the crops turn out bad then this will hit the whole family. In such a case one has to depend on others in order to hedge for unpredictable weather.

In Polish literature, research on social capital was popularized by Janusz Czapiński [2007]. His main take away is that Poland lacks social capital and trust among citizens what, in effect, becomes a major obstacle in the development of a modern knowledge-based economy. This point seems, unfortunately, to be true in many respects. Poland, along with other post-soviet economies, shows a very low level of social trust [Kääriäinen, Lehtonen, 2006]. Other Polish scientists come to a similar conclusion [Growiec, Growiec, 2011; Węziak-Białowolska, 2010]. Poles do not trust one another and they do not participate in associations.

Why is it so? The usual suspects are communism and the history of partitions of Poland. While it is hard to test the impact of communism, the impact of partitions can be to some extent verified. The country lost its independence in a series of annexations from 1772 to 1795 and regained it after the World War I. For over one century the country was divided into three different political entities with distinct political and economic institutions. In XIX century, Prussia was a rapidly modernizing country with a booming economy. Austro-Hungary was a melting pot of different nations and a relatively lower level of centralization. Russia was a large empire but relatively backward in economic terms and characteristic for its authoritarian political culture. If trust and social capital are historically-rooted then each partition should be affected in a different way, depending on the institutional and cultural framework prevailing in each of the three partitioning countries. This effect is weakened due to the fact that the borders of Poland shifted in the last 100 years and the population experienced large forced repatriations. Nonetheless, the Social Diagnosis panel with its sizable sample offers a possibility to test this hypothesis.

Other, potentially important historical factors, are ethnic diversity, literacy rate and urbanization. The interwar Poland was a multiethnic country with its citizens speaking different languages and following different religions. Polish Roman Catholics constituted only two-thirds of the population and Jews, Ukrainians, Belarusians and Germans constituted significant minorities each. These communities were partly segregated by language, religion and social stratum and as such their civic culture ought to have distinct features. Historical literacy rate is known to be positively related to generalized trust [Tabellini, 
2005; Guiso, Sapienza, Zingales, 2010]. Urbanization may not have direct effect on trust but it can mediate with effects of other demographic variables like ethnicity.

Finally, another factor that should be taken into account is migration. Poland experienced large flows of population after the World War I. Many Germans who found themselves living within Polish borders decided to leave and move to Weimar Republic. On the other hand, many Poles returned to Poland either from immigration in the West or from Soviet Union. Many Jews fled from Soviet Union to Poland too [Gawryszewski, 2005]. These migrations should have impact on the level of trust. Migrants take with them their culture of trust (or distrust) [Dohmen, Falk, Huffman, Sunde, 2007]. These effects tend to be lasting - for example, there exists a strong relation among citizens in USA between their current civic culture and the civic culture of European nations from which their ancestors came [Rice, Feldman, 1997].

\section{Method}

The survey data used in the analysis comes from Social Diagnosis [Diagnoza Społeczna] and covers waves 2009, 2011 and 2013. Choosing these particular waves is data-driven. Firstly, since 2009 the panel grew considerably in size what makes waves from 2009 onwards especially valuable. Secondly, the selection of questions in the panel varied over different years and thus it makes sense to keep only a sufficient number of waves, not more.

Both the 1921 and the 1931 Polish Censuses offer data at the powiat level. These were matched with current powiats. The general rule for matching powiats is as follows:

1. If both powiats, the pre-war and the current one, have the same capital, then these are matched together.

2. If a powiat has a different capital but is mostly within the borders of a pre-war powiat then these two are matched together.

These two rules were sufficient to match over 90 percent of powiats. In a few ambiguous cases the matching was constructed arbitrarily (e.g. an average of two powiats). Once the matching was done, 268 out of 380 contemporary powiats had their counterpart for the 1931 Census and 248 had a match for the 1921 Census. The lower number of matches for 1921 Census is caused by the fact that Silesia was not yet a part of Poland at the time of the 1921 census. Those powiats which were not within Polish borders prior to World War II do not have any matches and are used only in the beginning stages of the analysis. There are 112 of them and all were incorporated into Poland after the World War II. Prior to 1945 they constituted a part of Germany.

The data on ethnic minorities, literacy rate and on urbanization in the interwar Poland were taken from the 1931 Polish Census. Data on migration after the World War I were taken from the 1921 Census. 
1. Ethnicity. Religion is used as a proxy for ethnic composition. Roman Catholics are classified as Poles, Protestants as Germans, Orthodox Christians as Belarusian, Greek Catholics as Ukrainian and followers of Judaism as Jews. Belarusians and Ukrainians were merged into one category because both were mostly rural population living in Eastern Poland. There is no reason to claim they should have different levels of trust as their socio-economic status was very similar.

2. Literacy rate. Defined as the share of population that can both read and write.

3. Urbanization. Share of citizens living in cities.

4. Migration. Share of population that was born in the municipality was used as proxy for migration. Those who were not born in the municipality were split into two categories - those who live in there less than 10 years and those who live there longer. Those who live less than 10 years are supposed to be the result of the post-World War I migration and repatriation.

The analytical approach presented in the paper is based on logit regressions. This is due to the fact that the measure of generalized trust used in Social Diagnosis is binary ("most people can be trusted" vs. "you can't be too careful in dealing with people"). The impact of historical variables is controlled for a set of control variables. The regressions capture the effect of historical variables separately (Table 1) as well as include interactions (Table 2).

\section{Results}

The analysis presented in this section consists of a set of logit regressions and table 1 shows models where each historical variable is introduced separately. Each time control variables are used. The basic model covers age, age squared, sex, size of municipality and years of education (column 1). All of these variables are statistically significant. However only two play a major role - these are age and education. More educated Poles are more trusting which is in line with findings in literature on social capital [Alesina, Giuliano, 2009; Guiso, Sapienza, Zingales, 2003]. As well, Poles aged 15-20 are more trusting than all other age groups and this fact lays behind the non-linear character of the age-trust relationship. The phenomenon of higher trust among teenagers was already highlighted by Czapiński [2007]. It is as well frequent among post-soviet societies. This raises important questions about the transmission of trust. Guiso, Sapienza and Zingales [2007] suggested a transmission mechanism where parents transmit a conservative prior to their children. It is only due to interactions with others in the society that children learn to be more trusting. This pattern of conservative priors does not take place in Poland. In the case of Polish society, teenagers aged 15 show a higher level of generalized trust which drops as they age and by the age of 25 reaches the low level of trust characteristic for the overall population. This drop can be both seen on figure 1 and in any of the regression models reported in the paper. 
Given this evidence, it may suggest to assume that children receive neutral priors and once they grow up they learn to either trust or distrust depending on the culture prevalent in a society. In high-trusting societies children would learn to trust more in their adolescence. In low-trust societies they would learn to distrust. Such theory would fit both the findings obtained when analyzing Western societies and post-communist ones.

\section{FIGURE 1. Generalized trust across age groups}

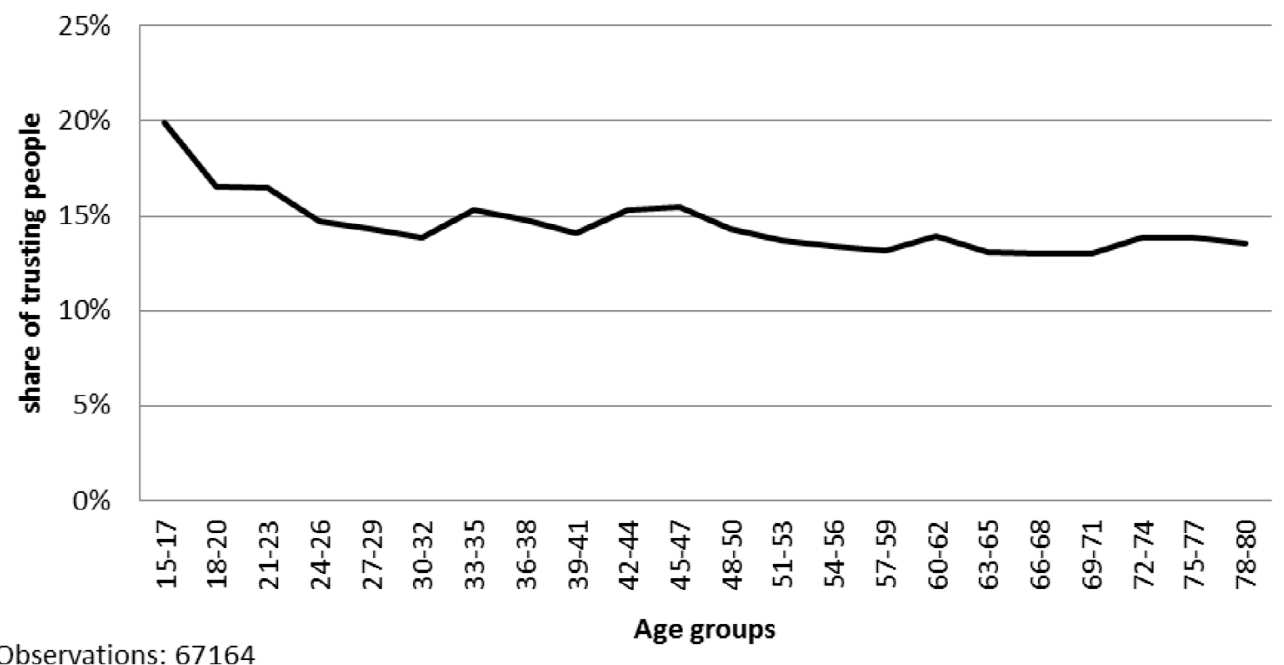

Observations: 67164

S ource: own elaboration.

Column 2 shows a model which tests the impact of Polish partitions. None of the outcomes are statistically significant. This gives support to the view that the history of partitions had less, if any, impact on trust. Still, it must be remembered that it is only an indirect way of testing this hypothesis because the true counterfactual is not available. There is simply no possibility to compare the current society to a society were partitions did not happen at all and the XIX-century Poland was self-governed by Poles.

Ethnic composition does play a role and the Eastern regions of Poland which historically had Belarusian of Ukrainian minorities show a lower level of trust (column 3). When ethnic composition is added into the model the size of the municipality becomes statistically insignificant. Regions with German minorities exhibit a lower level trust too but this relationship is weaker. Ethnicity often plays a role in research conducted in other countries. In this case, however, it is not clear why the areas with a higher ratio of Belarusians and Ukrainians should exhibit lower trust. 
The pre-war urbanization rate is positively associated with current levels of generalized trust (column 4). On the other hand, literacy rate is negatively associated with trust. This is against findings in the literature. Usually, historically higher literacy rate is associated with higher levels of trust [Guiso, Sapienza, Zingales, 2010]. Even the current education level measured by years of schooling has a strong positive relationship. Maybe this is the effect of war and communism - better educated population had a much higher chance of being targeted by persecution. But this remains only a hypothesis which is not tested here. Finally, migrations, both associated with the World War I and in the period before the War, had no impact on current levels of trust (column 5).

\section{TABLE 1. Impact of historical factors}

\begin{tabular}{|c|c|c|c|c|c|}
\hline & \multicolumn{5}{|c|}{ Dependent variable: Generalized trust } \\
\hline & $(1)$ & $(2)$ & $(3)$ & $(4)$ & $(5)$ \\
\hline \multirow[t]{2}{*}{ Intercept } & -1.917 & -1.905 & -2.053 & -1.969 & -2.054 \\
\hline & $(0.094)$ & $(0.095)$ & $(0.113)$ & $(0.128)$ & $(0.128)$ \\
\hline \multirow[t]{2}{*}{ Age } & $-0.030^{\star * \star}$ & $-0.030^{* * *}$ & $-0.034^{* * *}$ & $-0.034^{\star \star \star}$ & $-0.034^{* \star *}$ \\
\hline & $(0.003)$ & $(0.003)$ & $(0.004)$ & $(0.004)$ & $(0.004)$ \\
\hline \multirow[t]{2}{*}{ Age - squared } & $0.000^{\star * *}$ & $0.000^{\star \star \star}$ & $0.000^{\star * *}$ & $0.000^{\star \star \star}$ & $0.000^{\star * \star}$ \\
\hline & $(0.000)$ & $(0.000)$ & $(0.000)$ & $(0.000)$ & $(0.000)$ \\
\hline \multirow[t]{2}{*}{ Gender } & $-0.100^{* * *}$ & $-0.100^{\star * \star}$ & $-0.084^{\star * *}$ & $-0.084^{\star * *}$ & $-0.084^{\star * \star}$ \\
\hline & $(0.022)$ & $(0.022)$ & $(0.025)$ & $(0.025)$ & $(0.025)$ \\
\hline \multirow[t]{2}{*}{ Municipality size } & $-0.018^{\star *}$ & $-0.018^{\star *}$ & 0.004 & 0.012 & -0.004 \\
\hline & $(0.006)$ & $(0.006)$ & $(0.008)$ & $(0.011)$ & $(0.009)$ \\
\hline \multirow[t]{2}{*}{ Years of education } & $0.082^{\star * *}$ & $0.082^{\star * *}$ & $0.091^{\star * *}$ & $0.091^{\star * *}$ & $0.091^{\star * *}$ \\
\hline & $(0.004)$ & $(0.004)$ & $(0.004)$ & $(0.004)$ & $(0.004)$ \\
\hline \multirow[t]{2}{*}{ Pre-war Germany } & & -0.009 & & & \\
\hline & & $(0.029)$ & & & \\
\hline \multirow[t]{2}{*}{ German partition } & & -0.035 & & & \\
\hline & & $(0.029)$ & & & \\
\hline \multirow[t]{2}{*}{ Austrian partition } & & -0.008 & & & \\
\hline & & $(0.032)$ & & & \\
\hline \multirow[t]{2}{*}{ Jews } & & & 0.002 & & \\
\hline & & & $(0.001)$ & & \\
\hline \multirow[t]{2}{*}{ Ukrainians, Belarusians } & & & $-0.006^{\star *}$ & & \\
\hline & & & $(0.002)$ & & \\
\hline \multirow[t]{2}{*}{ Germans } & & & $-0.006^{*}$ & & \\
\hline & & & $(0.003)$ & & \\
\hline \multirow[t]{2}{*}{ Urbanization } & & & & $0.001^{*}$ & \\
\hline & & & & $(0.001)$ & \\
\hline
\end{tabular}




\begin{tabular}{|l|c|c|c|c|c|}
\hline \multirow{2}{*}{} & \multicolumn{5}{|c|}{ Dependent variable: Generalized trust } \\
\cline { 2 - 6 } & $(1)$ & $(2)$ & $(3)$ & $(4)$ & $(5)$ \\
\hline \multirow{2}{*}{ Literacy rate } & & & & $-0.002^{* *}$ & $(0.001)$ \\
\hline \multirow{2}{*}{$\begin{array}{l}\text { Pre-IWW immigrants - over 10 } \\
\text { years in municipality }\end{array}$} & & & & & -0.002 \\
\cline { 2 - 6 } & & & & & $(0.004)$ \\
\hline $\begin{array}{l}\text { IWW immigrants - less than 10 } \\
\text { years in municipality }\end{array}$ & & & & & 0.002 \\
\hline & & & & & $(0.002)$ \\
\hline Observations & 69566 & 69566 & 52715 & 52715 & 52715 \\
\hline $\mathrm{R}^{2}-$ Cox and Snell & 0.010 & 0.010 & 0.012 & 0.012 & 0.012 \\
\hline $\mathrm{R}^{2}$ - Nagelkerke & 0.018 & 0.018 & 0.021 & 0.021 & 0.021 \\
\hline
\end{tabular}

Logit regressions. ${ }^{*},{ }^{* *}$ and ${ }^{* * *}$ indicates significance at the $0.05,0.01$ and 0.001 level. Respondents from the area of pre-war Germany were used only in estimating models 1 and 2 and were excluded from further analysis. Dummy variables for panel waves are included.

S ource: own elaboration.

To capture interactions, the models in table 2 use a gradually increasing number of variables. Models 1-3 test ethnicity, literacy rate, urbanization and migration together with the Partitions of Poland. Model 4 uses partitions, ethnicity, urbanization and literacy rate and model 5 uses all of the variables.

Ethnicity is still relevant when additional variables are being added. When controlled for partitions, regions with a higher ratio of Ukrainians, Belarusians and Germans still show a lower level of trust (column 1). The same is true for lower levels of trust associated with a higher literacy rate in the interwar period (column 2).

Interestingly, when the effect of migration is controlled for partitions it becomes statistically significant (column 3). It is the migration in years 1911-1921 that has a strong positive effect on current levels of trust. The migration before 1911 does not have any effect. Furthermore, the effect of German partition becomes negative and statistically significant. This should be faced with historical facts. At the end of World War I many Germans lived in Greater Poland and Pomerania. In some areas they constituted the majority of the population. Once these lands where joined into Poland many of them migrated to Weimar Republic and Poles migrated to fill the void [Gawryszewski, 2005, pp. 302-305]. The parameters from model 3 can be interpreted as follows - the overall level of trust in Greater Poland and Pomerania is lower than in other regions but in the areas which experienced large influx of Polish migrants the level of trust is higher. This suggests that a large influx of migrants allowed to weaken the grip of low-trust cultural traits in the community. The outcomes presented in column 3 and 5 suggest that such mechanism is plausible and that it is not immigration per se but its disrupting effect it has on the cultural patterns. The fact that migration prior to 1911 had no impact supports this view. A gradual migration 
has no effect because when immigrants arrive gradually then they are much more likely to adapt to local culture. If the migration is large and abrupt then the impact on overall culture in the community should be much larger. An alternative explanation is that large migrations are only an indicator of large share of German population and that it is the German culture that left the positive effect of higher trust. This explanation, however, does not fit the data. Protestantism, the proxy for German minority, is not positively associated with trust (columns 1, 4, 5). In addition, the fact that the regions of Greater Poland and Pomerania, which belonged to Prussia, have lower levels of trust does not support the idea of positive impact of German culture either. It should be noted that this finding fits the outward exposure hypothesis [Ermisch, Gambetta, 2010]. Large and rapid influx of newcomers simply forces locals to cooperate with people who they do not personally know what, in effect, raises generalized trust among the citizens.

A model with all the variables included reiterates previous findings (column 5). It is the migration in years 1911-1921 and ethnicity that do have impact. Literacy rate and German partition have impact as well but it is weaker and urbanization has no impact at all.

TABLE 2. Impact of historical factors (interactions between variables)

\begin{tabular}{|c|c|c|c|c|c|}
\hline & \multicolumn{5}{|c|}{ Dependent variable: Generalized trust } \\
\hline & $(1)$ & $(2)$ & (3) & $(4)$ & $(5)$ \\
\hline \multirow[t]{2}{*}{ Intercept } & -2.065 & -1.970 & -2.242 & -1.984 & -2.196 \\
\hline & $(0.123)$ & $(0.128)$ & $(0.135)$ & $(0.134)$ & $(0.154)$ \\
\hline \multirow[t]{2}{*}{ Age } & $-0.034^{* * *}$ & $-0.034^{\star * *}$ & $-0.034^{\star * *}$ & $-0.034^{\star * *}$ & $-0.033^{* * *}$ \\
\hline & $(0.004)$ & $(0.004)$ & $(0.004)$ & $(0.004)$ & $(0.004)$ \\
\hline \multirow[t]{2}{*}{ Age - squared } & $0.000^{* * *}$ & $0.000^{* * *}$ & $0.000^{\star * *}$ & $0.000^{\star * *}$ & $0.000^{\star * *}$ \\
\hline & $(0.000)$ & $(0.000)$ & $(0.000)$ & $(0.000)$ & $(0.000)$ \\
\hline \multirow[t]{2}{*}{ Gender } & $-0.084^{* * *}$ & $-0.084^{\star * *}$ & $-0.084^{\star * *}$ & $-0.084^{\star * *}$ & $-0.084^{* * *}$ \\
\hline & $(0.025)$ & $(0.025)$ & $(0.025)$ & $(0.025)$ & $(0.025)$ \\
\hline \multirow[t]{2}{*}{ Municipality size } & 0.005 & 0.014 & 0.010 & 0.017 & 0.025 \\
\hline & $(0.010)$ & $(0.011)$ & $(0.010)$ & $(0.012)$ & $(0.013)$ \\
\hline \multirow[t]{2}{*}{ Years of education } & $0.091^{* * *}$ & $0.091^{* * *}$ & $0.091^{\star * *}$ & $0.091^{* * *}$ & $0.091^{\star * *}$ \\
\hline & $(0.004)$ & $(0.004)$ & $(0.004)$ & $(0.004)$ & $(0.004)$ \\
\hline \multirow{2}{*}{$\begin{array}{l}\text { German partition } \\
\text { (for col. } 3 \text { and } 5 \text { Silesia excluded) }\end{array}$} & 0.011 & 0.020 & $-0.249^{* * *}$ & 0.035 & $-0.153^{*}$ \\
\hline & $(0.046)$ & $(0.033)$ & $(0.054)$ & $(0.048)$ & $(0.068)$ \\
\hline \multirow[t]{2}{*}{ Austrian partition } & 0.004 & 0.027 & 0.011 & 0.038 & 0.057 \\
\hline & $(0.033)$ & $(0.035)$ & $(0.033)$ & $(0.036)$ & $(0.037)$ \\
\hline \multirow[t]{2}{*}{ Jews } & 0.002 & & & 0.001 & 0.002 \\
\hline & $(0.002)$ & & & $(0.002)$ & $(0.002)$ \\
\hline
\end{tabular}




\begin{tabular}{|c|c|c|c|c|c|}
\hline & \multicolumn{5}{|c|}{ Dependent variable: Generalized trust } \\
\hline & $(1)$ & $(2)$ & (3) & $(4)$ & $(5)$ \\
\hline \multirow[t]{2}{*}{ Ukrainians, Belarusians } & $-0.006^{\star *}$ & & & $-0.006^{* *}$ & $-0.005^{\star *}$ \\
\hline & $(0.002)$ & & & $(0.002)$ & $(0.002)$ \\
\hline \multirow[t]{2}{*}{ Germans } & $-0.006^{*}$ & & & -0.004 & -0.006 \\
\hline & $(0.003)$ & & & $(0.003)$ & $(0.004)$ \\
\hline \multirow[t]{2}{*}{ Urbanization } & & $0.001^{*}$ & & 0.001 & 0.000 \\
\hline & & $(0.001)$ & & $(0.001)$ & $(0.001)$ \\
\hline \multirow[t]{2}{*}{ Literacy rate } & & $-0.003^{* *}$ & & $-0.003^{* *}$ & $-0.002^{*}$ \\
\hline & & $(0.001)$ & & $(0.001)$ & $(0.001)$ \\
\hline \multirow{2}{*}{$\begin{array}{l}\text { Pre-IWW immigrants - over } 10 \\
\text { years in municipality }\end{array}$} & & & -0.003 & & -0.002 \\
\hline & & & $(0.004)$ & & $(0.004)$ \\
\hline \multirow{2}{*}{$\begin{array}{l}\text { IWW immigrants - less than } 10 \\
\text { years in municipality }\end{array}$} & & & $0.010^{* * *}$ & & $0.010^{* * *}$ \\
\hline & & & $(0.002)$ & & $(0.002)$ \\
\hline Observations & 52715 & 52715 & 52715 & 52715 & 52715 \\
\hline $\mathrm{R}^{2}-$ Cox and Snell & 0.012 & 0.012 & 0.012 & 0.012 & 0.013 \\
\hline $\mathrm{R}^{2}$ - Nagelkerke & 0.021 & 0.021 & 0.022 & 0.022 & 0.022 \\
\hline
\end{tabular}

Logit regressions. ${ }^{*}{ }^{* *}$ and ${ }^{* * *}$ indicates significance at the $0.05,0.01$ and 0.001 level. For analyses with data from 1931 and 1921 censuses the area of pre-war Germany was excluded. There is no data for Silesia in the 1921 census. As such in models 3 and 5 Silesia is used in the analysis but flagged as no response. In effect, the parameter for German partition is only for Pomerania and Greater Poland regions. Dummy variables for panel waves are included.

Source: own elaboration.

\section{Conclusion}

The outcomes presented in this paper suggest that social capital, as measured by generalized trust, in the modern Polish society does have roots in the past. Some of the findings fit into the intuitive understanding of how things played out in the past. Others contradict the outcomes usually founded in the literature.

The first hypothesis stated that partitions had potentially negative impact on social trust. However, the analysis presented in the paper gives little support for this view. There are little differences in generalized trust between three Polish partitions and ex-German lands. Once controlled for migration after the World War I, Greater Poland and Pomerania turn out to have slightly lower levels of trust. This depicts a story of only a lukewarm effect of Polish Partitions. Unfortunately, this is only an indirect proof because we can- 
not compare the outcomes with the true counterfactual which in this case would be the outcome for a Poland without the experience of partitions.

Other characteristics of the interwar Polish society do interplay with contemporary levels of trust. Those regions which historically had a higher share of Ukrainians and Belarusians show a lower level of trust. Interestingly, regions with a higher literacy rate during the interwar period exhibit lower level of trust. The latter outcome is surprising as it goes against the findings common in the literature [Guiso, Sapienza, Zingales, 2010]. These two effects are not very strong but statistically significant. There is no obvious mechanism that would explain how literacy and ethnicity would impact trust in such a way.

Finally, migration proves to have impact on trust too. The migrations and repatriations during and post-World War I prove to have positive impact on trust in modern Polish society. This can be explained by the outward exposure hypothesis [Ermisch, Gambetta, 2010]. Large influx of newcomers forced the local population to cooperate with newcomers and, in effect, loosened the grip of the low-trust culture. It is not the effect of migration per se because the migrations prior to World War I did not have that impact. It is the abrupt influx of large numbers of citizens that is able to loosen the grip of low-trust culture. It cannot be explained by the legacy of German minority who lived in the high-migration regions. The proxy for German minority - share of protestants in the powiat - turns out not to be significant. These findings suggest that an abrupt migration post World War I was able to alleviate generalized trust via the effect of outward exposure.

\section{Further Research}

As the paper shows, the analysis of historical data is a promising venue for the research of determinants of trust and social capital in Polish society. A promising idea is to verify the impact of socio-economic life in rural areas in the early industrial or pre-industrial Poland. The main problem here is, naturally, the availability of data. This paper's focus on interwar Poland was mainly driven by the availability of data in 1921 and 1931 censuses. So the numbers are in one place and ready to use. Any analysis that goes further into the past will encounter problems with collecting the data. It may require collecting scant information from various sources.

Another promising venue is to analyze the impact of communism. Here there is plenty of data. Such analyses are usually done by country comparison. This approach was taken by many scholars. However, it sets limits to the analysis because the sample of countries which can be included is small. If the goal is to focus solely on Polish society then another problem arises. Namely, there is no counterfactual available because the whole Polish society experienced communism. A way to overcome this limitation is to identify variables which could serve as proxies for the impact of communism. It is not hard to imagine variables 
which could to some extent achieve this goal. Profession is a good candidate, as it can be argued that some areas of professional life were more tainted by communism than others (e.g. state agricultural farms or heavy industry versus small private enterprises that were allowed to function even during communism). Age is another candidate. If communism is responsible for distrust among Poles then this should have a cohort effect. Those who lived under communism should exhibit lower levels of trust. Still, the use of such proxy variables would require a comprehensive theoretical background in order to be reliable.

\section{References}

Alesina, A., Giuliano, P. (2009), Family Ties and Political Participation, National Bureau of Economic Research, Working paper 15415.

Alesina, A., La Ferrar, E. (1999), Participation in Heterogeneous Communities, National Bureau of Economic Research, Working paper 7155.

Alesina, A., La Ferrara E. (2002), Who Trusts Others?, Journal of Public Economics, 85, pp. 207-234.

Almond, G., Verba S. (1965), The Civic Culture: Political Attitudes and Democracy in Five Countries, Princeton University Press.

Barr, A. (2000), Social Capital and Technical Information Flows in the Ghanaian Manufacturing Sector, Oxford Economic Papers, 52, pp. 539-59.

Bianchi, S., Robinson, J. (1997), What Did You Do Today? Children's Use of Time, Family Composition, and the Acquisition of Social Capital, Journal of Marriage and the Family, 59, pp. 332-344.

Bjørnskov, C. (2007), Determinants of generalized trust: A cross-country comparison, Public Choice, 130, pp. 1-21.

Bourdieu, P. (1986), The Forms of Capital, in: Handbook of Theory and Research for the Sociology of Education, ed. Richardson, J., Greenwood Press.

Coleman, J. (1988), Social Capital in the Creation of Human Capital, American Journal of Sociology, 94, pp. 95-121.

Costa, D., Kahn, M. (2003), Understanding the Decline in American Social Capital, 1952-1998, Kyklos, 56, pp. 17-46.

Czapiński, J. (2007), Kapitał ludzki i kapitał społeczny a dobrobyt materialny: polski paradoks, (Human Capital, Social Capital and Material Welfare: Polish Paradox), Warsaw University, unpublished.

Delhey, J., Newto, K. (2005), Predicting cross-national levels of social trust: global pattern or Nordic exceptionalism?, European Sociological Review, 21, pp. 311-327.

Diagnoza Społeczna (2013), “Diagnoza Społeczna 2013. Warunki i Jakość Życia Polaków”, (Social Diagnosis 2013. Objective and Subjective Quality of Life in Poland), Contemporary Economics, 7.

Dohmen, T., Falk, A., Huffman, D., Sunde U. (2007), The Intergenerational Transmission of Risk and Trust Attitudes, IZA. Discussion Paper No. 2380.

Durante, R. (2009), Risk, Cooperation and the Economic Origins of Social Trust: An Empirical Investigation, Munich Personal RePEc Archive.

Durlauf, S., Fafchamp, M. (2005), Social Capital, in: Handbook of Economic Growth, ed. Aghion P. and Durlauf S., Amsterdam: North Holland. 
EACEA/Eurydice (2012), The European Higher Education Area, in: 2012: Bologna Process Implementation Report, Brussels: EACEA P9 Eurydice.

Ermisch, J., Gambetta, D. (2010), Do Strong Family Ties Inhibit Trust?, Journal of Economic Behavior \& Organization, 75, pp. 365-376.

Fukuyama, F. (1995), Trust: The Social Virtues and the Creation of Prosperity, New York: Free Press.

Gawryszewski, A. (2005), Ludność Polski w XX wieku (The Population of Poland in the 20th Century), Warsaw: Polish Academy of Sciences.

Główny Urząd Statystyczny [Central Statistical Office] (2012), Incomes and Living Conditions of the Population of Poland, Warsaw: GUS.

Granovetter, M. (1975), Getting a Job: A Study of Contacts and Careers, Chicago: University of Chicago Press.

Growiec, K., Growiec, J. (2011), Trusting only whom you know, knowing only whom you trust: the joint impact of social capital and trust on individuals' economic performance and happiness in CEE countries, National Bank of Poland, Working Paper 94.

Guiso, L., Sapienz, P., Zingales, L. (2003), People's opium? Religion and economic attitudes, Journal of Monetary Economics, 50, pp. 225-282.

Guiso, L., Sapienza, P., Zingale, L. (2007), Social Capital as Good Culture, National Bureau of Economic Research, Working Paper 13712.

Guiso, L., Sapienza, P., Zingale, L. (2010), Civic Capital as the Missing Link, National Bureau of Economic Research, Working Paper 15845.

Hall, R.E., Jones, C.I. (1999), Why Do Some Countries Produce So Much More Output per Worker than Others?, Quarterly Journal of Economics, 114, pp. 83-116.

Halpern, D. (2005), Social Capital, Cambridge: Polity Press.

Johnson, S., McMillan, J., Woodruff, C. (2000), Entrepreneurs and the Ordering of Institutional Reform: Poland, Slovakia, Romania, Russia and Ukraine Compared, Economics of Transition, 8, pp. 1-36.

Kääriäinen, J., Lehtonen, H. (2006), The Variety of Social Capital in Welfare State Regimes - a Comparative Study of 21 Countries, European Societies, 8, pp. 27-57.

Nunn, N., Wantchekon, L. (2009), The Slave Trade and the Origins of Mistrust in Africa, National Bureau of Economic Research, Working Paper 14783.

OECD (2013), PISA 2012 Results in Focus, PISA, OECD Publishing.

Putnam, R., Leonardi, R., Nanetti R. (1993), Making Democracy Work: Civic Traditions in Modern Italy, Princeton: Princeton University Press.

Putnam, R. (2000), Bowling Alone: The Collapse and Revival of American Community, New York: Simon and Schuster.

Regulski, J. (2013), Bolesna samorządowa czkawka (Painful hiccup of local administration), Dziennik Gazeta Prawna, November 11-13, A2.

Rice, T., Feldman, J. (1997), Civic culture and democracy from Europe to America, Journal of Politics, 59, pp. 1143-72.

Smolar, A. (2014), Polacy sobie nie ufają (Poles do not trust one another), Fakt, February 5.

Solow, R. (1995), Trust: The Social Virtues and the Creation of Prosperity (Book Review), The New Republic, 213, pp. 36-40.

Soroka, S., Helliwell, J., Johnston, R. (2007), Measuring and Modelling Trust, in: Diversity, Social Capital and the Welfare State, ed. F. Kay and R. Johnston, Vancouver: University of British Columbia Press. 
Tabellini, G. (2005), Culture and institutions: economic development in the regions of Europe, CESifo working papers, No. 1492.

Uslaner, E.M. (2002), The moral foundations of trust, Cambridge University Press.

Węziak-Białowolska, D. (2010), Kapitał społeczny w Polsce - propozycja pomiaru i wyniki (Social Capital in Poland - Suggestion on Measurement and Results), Zeszyty naukowe, Instytut Statystyki i Demografii SGH, 4.

Zak, P., Knack, S. (2001), Trust and Growth, Economic Journal, 111, pp. 295-321. 